Original Research

\title{
A COMPARISON OF THE EFFECTIVENESS OF HEALTH EDUCATION METHODS ON ANXIETY LEVELS AMONG PRE-CATARACT SURGERY PATIENTS IN CENTRAL JAVA, INDONESIA
}

\section{Shinta Restu Wibawa*, Suharjo, Ibrahim Rahmat}

Faculty of Medicine, Public Health and Nursing, Universitas Gadjah Mada

Received: 6 December 2018 | Revised: 10 December 2018 | Accepted: 17 December 2018

*Correspondence:

Shinta Restu Wibawa

Faculty of Medicine, Public Health and Nursing, Universitas Gadjah Mada

J1. Farmako, Senolowo, Sekip Utara, Kec. Depok, Kabupaten Sleman, Daerah Istimewa Yogyakarta 55281, Indonesia

Email: wibawasinta@gmail.com

Copyright: (C) the author(s), YCAB publisher and Public Health of Indonesia. This is an open-access article distributed under the terms of the Creative Commons Attribution Non-Commercial License, which permits unrestricted non-commercial use, distribution, and reproduction in any medium, provided the original work is properly cited.

\begin{abstract}
Background: Not much is known about the impact of health education in reducing anxiety levels in pre-cataract surgery patients in Indonesia.

Objective: The aim of this study was to compare the effectiveness of counseling and lecture methods using leaflet in reducing anxiety levels among pre-cataract surgery patients in Central Java, Indonesia.

Methods: This was quasi experiment with pretest- posttest design with two comparative groups at two hospitals in November 2014. It was 70 preoperative cataract patients selected using total sampling, which 35 randomly assigned to intervention group 1 and intervention group 2. The Analog Anxiety Scale (AAS) was used to measure anxiety levels. Data were analyzed using paired t-test and independent t-test.

Results: There was a significant effect of health education using counseling and lecture method with leaflet media in reducing anxiety levels among preoperative cataract patients $(\mathrm{p}=.001)$. A counseling method was more effective than lecture method in dealing with anxiety levels $(\mathrm{p}=.001)$.

Conclusion: Findings of this study can be used as a basis for development of nursing intervention in the hospital setting to reduce the anxiety levels among pre-cataract surgery patients.
\end{abstract}

Keywords: anxiety, health education, cataract surgery, nursing

\section{BACKGROUND}

A cataract is a clouding condition in the normally clear lens, which occurs due to changes in the protein and lens fibers (Maloring, Kaawoan, \& Onibala, 2014). In Indonesia, the results of the blindness survey using the new Rapid Assessment of Avoidable Blindness (RAAB) method in 3 provinces (NTB, West Java and South Sulawesi) in 2013-2014 found that the prevalence of blindness in people aged $>50$ years in the 3 provinces was $3.2 \%$ of cases caused by cataract (71\%) (Riskesdas, 2013). In Central Java, there was $1.1 \%$ of population suffered from low vision. There are two main reasons for patients with cataract who have not undergone surgery, namely ignorance and psychosocial problem such as anxiety or afraid of being operated (Riskesdas, 2013).

Unfortunately, until today there is no single study to treat cataract, except surgery. Thus, patients should be well informed to deal with 
their anxiety. Anxiety is a condition characterized by feelings of fear accompanied by cognitive, motoric, affective, and somatic signs that cause autonomic nervous system hyperactivity (Suardana \& Simarmata, 2013). Another study also mention that the symptoms of anxiety can include anxiety, fear, increased heart rate, insomnia, nausea and autonomic symptoms (Chandratika \& Purnawati, 2014). Although anxiety is very common among cataract patients, however, without the treatment it will lead to anxiety disorder (Springer, Levy, \& Tolin, 2018). Anxiety will appear on a small or large scale at the time of preoperation (Springer et al., 2018). Dealing with anxiety itself depends on the level of emotional, how to adapt, and from the patient's anxiety level (Strelau \& Zawadzki, 2011).

Our preliminary study with 107 cataract patients in 7 hospitals showed that most of them experienced anxiety and majority of them were unable to sleep. The health education given by health workers, both doctors and nurses, before surgery was also limited. This condition leads to our interest to know whether pre-operative health education is still effective or not. Our present study aimed to identify the effectiveness of health education on anxiety among pre-operative cataract patients and to compare two methods of health education between counseling with leaflet (individual approach) and lecture with leaflet (group approach).

\section{METHODS}

\section{Study design}

This was quasi experiment with pretestposttest design with two comparative groups. The study was conducted at Tidar Public Hospital Magelang and Banjarnegara Public Hospital on November 2014.

\section{Sample}

Seventy preoperative cataract patients were selected using total sampling, which 35 randomly assigned to group 1 (those who received health education using counseling and leaflet) and group 2 (those who received health education using lecture and leaflet). The inclusion criteria of the sample were: 1) preoperative cataract patients, 2) able to read and write, 3) no hearing loss, and 4) never performed cataract surgery before. The exclusion criteria were those who had other eye disorders. During data collection, there was one participant excluded from group 1 due to the occurrence of another eye disorder.

\section{Instrument}

The Analog Anxiety Scale (AAS) was used to measure anxiety levels. The instrument was adopted from previous study in Indonesian language with good validity and reliability (Yunitasari, 2013). Anxiety levels consisted of no anxiety (if score <150), mild anxiety (if score between 150 - 199), moderate anxiety (if score between 200 - 299), severe anxiety (if score between $300-399$ ) and panic (if score $>400)$.

\section{Intervention}

Group 1 (health education using counseling and leaflet)

The intervention in this group was basically based on individual approach, which one by one of the participants was given counseling using the leaflet as the media. The researchers with the team (eye nurses and medical residents) given the information regarding definitions, signs and symptoms of cataracts, the importance of cataract surgery, things to consider and carry out by patients before, during and after cataract surgery. The counseling was taken for 15 minutes in a special quite room in the hospital. After the counseling, the leaflet was given to the participants for them to learn at home. This intervention was done in Banjarnegara Hospital.

\section{Group 2 (health education using lecture and leaflet)}

The intervention in group 2 was given by the researchers using a lecture method and leaflet. All participants were gathered in the meeting room. The lecture was carried out for 15 minutes and continued with question and answer section. Similar with group 1, the topics to explain were related to definitions, 
signs and symptoms of cataracts, the importance of cataract surgery, things to consider and carry out by patients before, during and after cataract surgery. This intervention was done in Tidar General Hospital.

\section{Data collection}

Data were collected using AAS questionnaire by the researchers and the research assistants before and after given intervention in both group 1 and 2. The researchers ensured that all research assistants understood the objectives and the procedures of the study and its data collection.

\section{Data analysis}

As our data showed normal distribution indicated by the results of Kolmogorov Smirnov ( $p>.05)$, then we used independent ttest to compare the effect of health education between both groups, and paired t-test to analyze the effect of health education on anxiety levels in each group.

\section{Ethical consideration}

This research was approved by The Medical and Health Research Ethics Committee (MHREC) with approval number: KE / FK / 1215 / EC. Before retrieving data and intervening, the researcher explains the purpose of the research and the procedure to be carried out, where the results of the answers will be kept confidential and only for research purposes. Informed consent was given to respondents to be signed.

\section{RESULTS}

\section{Demographic characteristics of the participants}

The demographic characteristics of participants as shown in the Table 1 shows that the majority of participants were man $(52.5 \%), \quad>50$ years old $(84.1 \%)$, had elementary school background (53.6\%), and working as a farmer (55.1\%). The homogeneity test showed p-value $>.05$ in each variable, which indicated that the participants in the group 1 and 2 were homogeneous or no significant differences between them.

Table 1 Demographic characteristics of the participants $(n=69)$

\begin{tabular}{|c|c|c|c|c|}
\hline \multirow{2}{*}{ Characteristics } & \multicolumn{2}{|c|}{ Frequency } & \multirow{2}{*}{ Percentage } & \multirow{2}{*}{ p-value } \\
\hline & Group 1 & Group 2 & & \\
\hline \multicolumn{5}{|l|}{ Gender } \\
\hline Man & 19 & 17 & 52.5 & \multirow{3}{*}{.55} \\
\hline Woman & 15 & 18 & 47.8 & \\
\hline Total & 34 & 35 & 100 & \\
\hline \multicolumn{5}{|l|}{ Age } \\
\hline$<20$ years old & - & 1 & 1.4 & \multirow{4}{*}{.12} \\
\hline $20-50$ years old & 4 & 10 & 14.5 & \\
\hline$>50$ years old & 30 & 24 & 84.1 & \\
\hline Total & 34 & 35 & 100 & \\
\hline \multicolumn{5}{|l|}{ Education } \\
\hline None & 11 & 20 & 29.0 & \multirow{6}{*}{.49} \\
\hline Elementary school & 20 & 7 & 53.6 & \\
\hline Junior high school & 2 & 5 & 7.2 & \\
\hline Senior high school & 1 & 2 & 7.2 & \\
\hline Diploma & - & 1 & 2.9 & \\
\hline Total & 34 & 35 & 100 & \\
\hline \multicolumn{5}{|l|}{ Working status } \\
\hline Civil servant & - & 3 & 4.3 & \multirow{7}{*}{.55} \\
\hline Private employees & 1 & 2 & 2.9 & \\
\hline Entrepreneurship & 4 & 12 & 17.4 & \\
\hline Farmer & 24 & 10 & 55.1 & \\
\hline Housewife & 4 & 6 & 17.4 & \\
\hline Others & 1 & 2 & 2.9 & \\
\hline Total & 34 & 35 & 100 & \\
\hline
\end{tabular}


Table 2 Effect of health education on anxiety levels in group 1 and 2 using Paired t-test

\begin{tabular}{|c|c|c|c|c|c|}
\hline & $\mathbf{N}$ & $\begin{array}{c}\text { Anxiety level } \\
\text { Mean } \pm \text { SD }\end{array}$ & $\mathbf{t}$ & df & P-value \\
\hline \multicolumn{6}{|l|}{ Group 1} \\
\hline $\begin{array}{l}\text { Pretest } \\
\text { Posttest }\end{array}$ & $\begin{array}{l}34 \\
34\end{array}$ & $\begin{array}{l}234.11 \pm 59.54 \\
71.17 \pm 17.01\end{array}$ & 16.404 & 33 & $.001^{*}$ \\
\hline \multicolumn{6}{|l|}{ Group II } \\
\hline $\begin{array}{l}\text { Pretest } \\
\text { Posttest }\end{array}$ & $\begin{array}{l}35 \\
35\end{array}$ & $\begin{array}{l}230.00 \pm 62.87 \\
119.714 \pm 23.83\end{array}$ & 12.496 & 34 & $.001 *$ \\
\hline
\end{tabular}

*significant $(<.05)$

The results of paired t-test in the Table 2 show that $\mathrm{p}$-value was $.001(<.05)$ in group I and group 2, which indicated that there was a significant effect of given health education using counseling and leaflet as well as given using lecture and leaflet on anxiety levels among preoperative cataract patients. There was a significant decrease of the average level of anxiety in the group 1 from 234.11 (moderate anxiety) to 71.17 (no anxiety), and also the average level of anxiety in the group 2 from 230 (moderate anxiety) to 119.7 (no anxiety).

Table 3 Difference in the anxiety levels in group 1 and 2 after given intervention using Independent t-test

\begin{tabular}{|c|c|c|c|c|}
\hline \multirow{2}{*}{ Anxiety level } & Group $1(N=34)$ & Group $2(\mathrm{~N}=35)$ & \multirow{2}{*}{ t } & \multirow{2}{*}{ p-value } \\
\hline & Mean \pm SD & Mean \pm SD & & \\
\hline Pretest & $234.11 \pm 59.54$ & $230.00 \pm 62.87$ & 9.71 & $0.001 *$ \\
\hline Posttest & $71.17 \pm 17.01$ & $119.71 \pm 23.82$ & & \\
\hline Mean difference & $162.94 \pm 42.53$ & $110.29 \pm 39.05$ & 67 & $0.001 *$ \\
\hline
\end{tabular}

The results of Independent t-test (see Table 3) showed p-value .001 (<.05), which indicated that there was a significant difference in the effect of two comparative groups on the anxiety levels. The health education using counseling and leaflet was much better in reducing anxiety than health education using lecture and leaflet. There was also a significant mean difference in anxiety levels between the group 1 (162.94) and group 2 (110.29).

\section{DISCUSSIONS}

Findings of this study revealed that both health education techniques, counseling and lecture with leaflet media, had significant effect in reducing the anxiety levels among preoperative cataract patients. This finding provides the knowledge that these patients need health education to deal with their anxiety. This is in line with previous study that preoperative information reduce patient anxiety in the perioperative period of cataract surgery (Kekecs, Jakubovits, Varga, \& Gombos, 2014).
Certainly, the patients in this study had lack of knowledge about their disease and its surgery, which was also seen from their educational level that were mostly elementary school. They did not know what would happen before, during and after surgery. Similar with previous study said that patients who have not received education might not know what they experienced after the surgery. The patients will think differently and lead to anxiety and tension. According to previous study (Na'im, 2010), anxiety will narrow the field of individual perceptions, such as vision, hearing, and reduced gripping movements. Severe anxiety levels may occur during the informed consent process, in which the patient and surgeon discuss serious risks of the surgery. Thus, it is important for them to understand the risk of operation, complication, as well as the benefit of operation (Ramirez, Brodie, RoseNussbaumer, \& Ramanathan, 2017). Nurses need to play a key role at this point to deal with anxiety and responsible for the public health of individual and community (Gunawan, 2016).

Although both health education techniques were likely to be effective in reducing anxiety, 
however, our study showed that individual approach with counseling using leaflet had much better effect than group approach with lecture method. It may be due to lack of the time for questions and answers during the session, or the patients may feel shy to ask the questions and pretend that they understood.

Our study provides several implications for hospitals, namely: 1) findings of this study provides the evidence that health education using counseling and lecture with leaflet was still effective in reducing anxiety levels, 2) our study provides the insight of knowledge that counseling has a better impact than lecture method to reduce the anxiety levels among preoperative cataract patients, thus nurse counseling center may be needed to establish in the hospitals to provide health information to patients, 3) our study tells that the use of leaflet was still effective as a media for consultation in the today's era which mobile and smartphone are used by the majority of community.

The use of self-report data using questionnaire may be the limitation of this study, which enhances social desirability bias in the results, especially when measuring anxiety. In the waiting room patients showed high levels of anxiety, however when filling out the questionnaire majority of patients tend to underestimate their own level of anxiety. Thus, further study to understand anxiety comprehensively is needed.

\section{CONCLUSIONS}

There was a significant effect of health education using counseling and lecture method with leaflet media in reducing anxiety levels among preoperative cataract patients. A counseling method was more effective than lecture method in dealing with anxiety levels. Findings of this study serve as a basis for development of nursing intervention in the hospital setting and foundation for further research.

\section{ACKNOWLEDGMENT}

We acknowledge the Faculty of Medicine, Public Health and Nursing, Gadjah Mada University and the Indonesian Ophthalmologist Association for the valuable supports in this study. We also thank all participants who joined this study.

\section{REFERENCES}

Chandratika, D., \& Purnawati, S. (2014). Gangguan Cemas Pada Mahasiswa Semester I Dan VII Program Studi Pendidikan Dokter Fakultas Kedokteran Universitas Udayana. E Jurnal Medika Udayana, 3(1), 403-414.

Gunawan, J. (2016). Public Health Professionals and Nurses in Indonesia: Are We Partners? Public Health of Indonesia, 2(2), 112-113.

Kekecs, Z., Jakubovits, E., Varga, K., \& Gombos, K. (2014). Effects of patient education and therapeutic suggestions on cataract surgery patients: A randomized controlled clinical trial. Patient education and counseling, 94(1), 116122.

Maloring, N., Kaawoan, A., \& Onibala, F. (2014). Hubungan Pengetahuan Dan Sikap Dengan Kepatuhanperawatan Pada Pasien Post Operasi Katarak Di Balai Kesehatan Mata Masyarakat Sulawesi Utara. Jurnal Keperawatan, 2(2), 19.

Na'im, N. J. (2010). Hubungan Dukungan Keluarga Dengan Tingkat Kecemasan Ibu Primipara Menghadapi Persalinan Di Puskesmas Pamulang Kota Tangerang Selatan. Universitas Islam Negeri Syarif Hidayatullah, Jakarta.

Ramirez, D., Brodie, F., Rose-Nussbaumer, J., \& Ramanathan, S. (2017). Anxiety in patients undergoing cataract surgery: a pre-and postoperative comparison. Clinical ophthalmology (Auckland, NZ), 11, 1979-1986.

Riskesdas. (2013). Basic Health Research Report (Riset Kesehatan Dasar). Retrieved from Jakarta: http://www.depkes.go.id/resources/download/g eneral/Hasil Riskesdas 2013.pdf

Springer, K. S., Levy, H. C., \& Tolin, D. F. (2018). Remission in CBT for adult anxiety disorders: A meta-analysis. Clinical psychology review.

Strelau, J., \& Zawadzki, B. (2011). Fearfulness and anxiety in research on temperament: Temperamental traits are related to anxiety disorders. Personality and Individual Differences, 50(7), 907-915.

Suardana, A., \& Simarmata, N. (2013). Hubungan Antara Motivasi Belajar dan Kecemasan pada Siswa Kelas Vi Sekolah Dasar di Denpasar Menjelang Ujian Nasional. Jurnal Psikologi Udayana, 1(1), 203-212.

Yunitasari, L. N. (2013). Hubungan Beberapa Faktor Demografi Dengan Tingkat Kecemasan Pasien Pasca Diagnosis Kanker Di RSUP Dr. Kariadi 
Semareang. Medica Hospitalia Journal of Clinical Medicine, 1(2).
Cite this article as: Wibawa, S. R., Suharjo.,

Rahmat, I. (2018). A comparison of the effectiveness of health education methods on anxiety levels among pre-cataract surgery patients in Central Java, Indonesia. Public Health of Indonesia, 4(4): 162-167. 